\title{
EARLY Holocene ARCHAEOLOGY IN Grand Teton National Park
}

\author{
ROBERT L. KELLY $\uparrow$ DEPARTMENT OF ANTHROPOLOGY \\ UNIVERSITY OF WYOMING $\downarrow$ LARAMIE
}

The purpose of this investigation was to look for and determine the future utility of searching for Early Holocene (6000-12,000 year old) archaeological sites in Grand Teton National Park. Our previous proposal to GTNP stated that the evidence for an Early Holocene human occupation of Jackson Hole was extremely limited, but that this could be a function of investigators not having looked hard enough in the appropriate places. Part of our research was designed to determine where appropriate places' to focus our research might be, while the remainder of our study involved looking in these appropriate places. We conducted these two tasks primarily on the valley floor, rather than the mountains, as we did not expect sites of this age to be preserved in extremely steep and active terrain.

\section{$\downarrow \quad$ TASKS ACCOMPLISHED}

Based on what little is known of Jackson Hole Holocene (post-glacial) geology we searched for sites in three major areas: south of Jackson Lake, from Burnt Ridge east to the Snake River, along Pacific Creek, and in southern Jackson Hole, between Blacktail Butte and Kelly Warm Spring. As time allowed, some other areas were examined as well. We choose these areas based on two criteria: the probability of the exposed land surface being of sufficient age and sufficiently little erosion to preserve early Holocene artifacts, and the probability that cut banks might expose early Holocene deposits in profile. The former criteria led us to the area between the Snake River and Burnt Ridge as this area, the "potholes" region, preserves landscape features associated with the final glaciation of Jackson
Hole and therefore has not been significantly modified (by erosion, deposition or glaciation) for the past 11,000 years.

The surveys were conducted by $2-4$ archaeologists spaced about 20 meters apart. This is too far apart for an accurate recovery of isolated artifacts, but it is sufficient to locate major concentrations of archaeological debris. Visibility in many areas was less than desirable due to sagebrush and grass cover but we directed our search to those areas where the ground surface was exposed, and, since we were especially interested in looking for buried sites, to those areas where erosion, stream cuts, roads, etc. might have exposed subsurface material. Table 1 summarizes the tasks accomplished, a narrative of which follows.

\section{Jenny Lake and Moran Quads}

Potholes region and west. We surveyed a path through the potholes region about $1 / 4$ to $1 / 2$ mile east of Burnt Ridge as well as the southern tip of the ridge and a path along the east face of the Ridge, just east of the tree line. This survey recovered no prehistoric sites, although a pre-1900 cabin and associated corral were located (see Figure 1). A few pieces of FCR (firecracked rock) were found at 48TE408. The historic cabin and all other new sites mentioned in this report will be formally documented by Mr. Alan Bartholomew.

As shown in figures 2 and 3, we walked three other transects in this area, one along the upper (oldest) Snake River Terrace north of Deadman's Bar (in two 


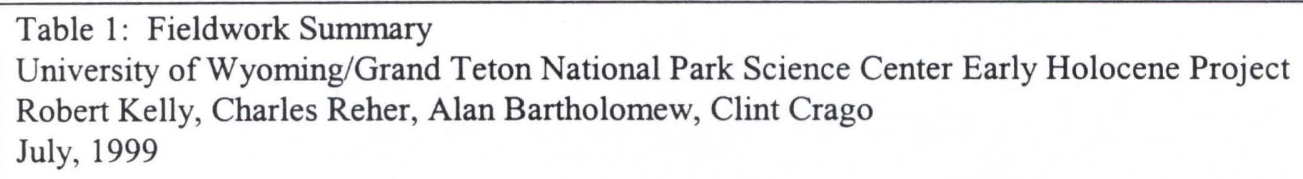

\begin{tabular}{|c|c|c|}
\hline$\underline{\text { Study Area }}$ & $\frac{\text { Transect }}{\text { Distance }}$ & $\underline{\text { Results }}$ \\
\hline Pacific Creek & $9.6 \mathrm{~km}$ & $\begin{array}{l}\text { Charcoal lense sample from highest terrace (probably } \\
\text { too small for dating, but exposure is worth revisiting) } \\
\text { on east side; second sample taken from lowest terrace } \\
\text { along east side of river near old homestead/irrigated } \\
\text { field site }\end{array}$ \\
\hline Ditch Creek/East Blacktail Butte & 6.4 & $\begin{array}{l}\text { Soil samples taken from } 2 \text { buried paleosols, no artifacts } \\
\text { observed; known historic trash scatters were revisited, } 1 \\
\text { new historic trash scatter located }\end{array}$ \\
\hline Cow Lake & 5.6 & $\begin{array}{l}\text { Historic corral located; protohistoric/historic tipi rings } \\
\text { located around Cow Lake }\end{array}$ \\
\hline Burnt Ridge and Potholes & 11.2 & $\begin{array}{l}\text { Auger tested four pothole bottoms, no archaeological } \\
\text { remains or paleosols observed; revisited rock alignment } \\
\text { site; early historic cabin/corral located }\end{array}$ \\
\hline Timbered Island & 1.6 & $\begin{array}{l}\text { Revisited Albert Sesenbach grave; no archaeological } \\
\text { remains located }\end{array}$ \\
\hline East of Hedrick Pond & 0.4 & Site recorded by Wright not observable \\
\hline $\begin{array}{l}\text { Snake River Terraces } \\
\text { (Above Deadman's Bar) }\end{array}$ & 9.6 & 2 isolates/small lithic scatters located \\
\hline Leigh Lake & 4.8 & $\begin{array}{l}\text { Auger test on east side of lake; } 2 \text { site revisits, } 2 \text { new } \\
\text { boulder shelters sites located }\end{array}$ \\
\hline South Blacktail Butte & & $\begin{array}{l}\text { Auger test of lithic scatter located previously-no buried } \\
\text { material observed. }\end{array}$ \\
\hline Two Ocean Lake & 0.8 & Auger test of Wright site at mouth of lake; 2 site revisits \\
\hline Kelly Warm Springs & & $\begin{array}{l}\text { Site revisits and auger test; auger did not reveal any } \\
\text { deeper deposits than already known from test pit }\end{array}$ \\
\hline BlackTail Ponds & & Site revisit \\
\hline Moose Ponds & & Site revisit \\
\hline Jenny Lake & & Site revisit \\
\hline Berry Creek & 24 & 2 site revisits, 3 new sites discovered, as yet unrecorded \\
\hline $\begin{array}{l}\text { Lower Snake River Terraces } \\
\text { (Deadman's Bar to Bar BC Ranch) }\end{array}$ & 6.7 & Several isolates; 3 new sites that new recording. \\
\hline
\end{tabular}

pieces) and two other short ones around two prominent potholes. A few isolated pieces of debitage were noted on three points along the terrace (of the survey section shown in Figure 2); additionally, we found a low swale filled with loess containing a paleosol about $1.5 \mathrm{~m}$ below the surface. This paleosol was not sampled as the probability of it containing sufficient carbon for dating is very low. No artifacts were found around the potholes.
A few isolated flakes were found in the Cow Lake survey (Figure 3); more importantly, we discovered an extensive historic site around the edges of Cow Lake. This site, which was recorded before we left the field, consists of a number of stone circles or rings and an historic trash scatter. A cursory examination of the historic trash points to a 1920 s occupation, but the stone rings suggest a Native American, not European presence. This site was recorded in more detail by Bartholomew and Crago. 
We also put several auger holes into the bottoms of potholes (Figures 1 and 2). Auger hole 1 showed gravels to $80 \mathrm{~cm}$, where the deposits shifted to clays, becoming progressively more sandy until they switched to gravels in clay at $190 \mathrm{~cm}$. We could not penetrate further.

Auger hole 2 (two efforts) was only able to penetrate to about $50 \mathrm{~cm}$, through gravels in aeolian loam.

Auger hole 3 contained clay with no gravel from the surface to about $60 \mathrm{~cm}$; the deposit shifted to sand at this point with increasingly less clay, then to a solid clay saturated with water and containing organic stains at $150 \mathrm{~cm}$. There was a return to dry sand at 180 $\mathrm{cm}$; this sand continued to $240 \mathrm{~cm}$, the limit of our auger probe. This pothole was the largest that we sampled, and the lack of gravel is most likely a product of the fact that the sides of the hole--the source of the colluvium in the other auger holes--are far from the center. In addition, this pothole's base showed signs of containing water at some time in the year (as indicated by the deep but dry bison footprints). This was also the topographically lowest pothole that we sampled. We did not core the sides of the bottom of this pothole, but if we did, we would probably have encountered considerably more gravels.

Auger hole 4 is again in a smaller pothole, one near a pothole containing standing water; it contained the gravels in a loamy matrix as above in the first 60 $\mathrm{cm}$, then clay until $110 \mathrm{~cm}$; sand, mixed with or resting on top of an impenetrable gravel layer was encountered at $130 \mathrm{~cm}$

At this point is it difficult to prove, but it is possible, that the clay layers in these potholes reflect higher water tables and thus may reflect Pleistocene accumulations. Definite dates (we located no material that could be dated) are needed to test this hypothesis. If true, however, then it means that the entire Holocene occupation of the potholes region would be contained in, at most, some $30-60 \mathrm{~cm}$ of the loamy gravel above the clays. In the areas between the potholes, there is no soil development, and so, outside the bottoms of the potholes, the entire prehistoric sequence would rest on the ground surface. Wright's fieldnotes indicate that he did locate a site 'on a ridge between two potholes' (of which there are quite a few in this area) but the site was neither recorded nor its location noted as the investigators did not bring their maps due to inclement weather.

We revisited a site at an odd rock structure at the north edge of the potholes, near Teton Park Road, composed of a linear arrangement of cobbles with at least three stone cairns. This site has not yet been assigned a number. We also surveyed the terraces along lower Pacific Creek on both sides of Highway 287 (Figure 4), including terrain on the Moran, Whetstone Mountain and Davis Hill quads. We revisited site 48TE439, at the confluence of the Snake River and Pacific Creek, finding only a single flake. Along the lowest terrace on the east side of Pacific Creek we located a cutbank containing a buried layer of burnt material about $35 \mathrm{~cm}$ below the modern ground surface and about $2-4 \mathrm{~cm}$ in thickness; this layer extended for nearly $100 \mathrm{~m}$. Several samples of this material was extracted for radiocarbon dating. A sample submitted for dating returned an age of $1340 \pm$ 60 B.P. $\left({ }^{13} \mathrm{C} /{ }^{12} \mathrm{C}=-25.0\right.$ o/oo, estimated; Calibrated to 1335 to 1165 B.P.; Beta lab number 134065). No prehistoric material was seen on this section of the transect, although there is a considerable amount of historic trash here, some quite late (post-1950s). We also surveyed the terraces along the creek draining from Two Ocean Lake just above where that creek joins Pacific Creek. No archaeological remains were found here, but a stream cut containing multiple layers of possibly burned material was noted and a sample of one of the lenses taken; this may not contain sufficient carbon for a date, however. The very late Holocene date on the deposit in this cutbank also suggests that if Early Holocene materials are to be located in this area, they are almost certainly deeply buried.

We then revisited three of Wright's sites, $48 \mathrm{TE} 357$ at the outlet of Two Ocean Lake on the north side of the drainage, and 48TE471 and 48TE472, on knolls to the east (Figure 5). We were able to locate a few flakes at each location, but no evidence of substantial deposit. At 48TE357 some fire-cracked rock and flakes were seen on the slope leading down to the creek that drains Two Ocean lake and while this suggested the possibility of a buried deposit, an auger probe showed no signs of buried deposit.

Finally, we revisited site 48TE441, to the Hedrick Pond (Figure 6), but we were unable to locate any archaeological remains.

Leigh Lake. We also surveyed the outlet of Leigh Lake, revisiting a known site, 48TE629, finding a small scatter of flakes on both sides of the outlet (Figure 7). Additionally, we located three erratics, two on the west and one on the east side of the outlet that had a few flakes at their bases. We also checked the large boulder on Boulder Island, finding only a single flake eroding from the slope to the south of the boulder, 
on the edge of the island. We surveyed the western side of the southern arm of Leigh Lake. Visibility was not good and we surveyed the area primarily by checking the soil around tree throws. Curious about the underlying stratigraphy we put a single hand auger test in. We found that the top $30 \mathrm{~cm}$ contains colluvium (coming from the hillslope to the west) and, below that, a thick layer of sand, more than 1 meter in thickness. We suspect that this sand is Pleistocene in age as it would have been deposited along a beach when the lake was at a higher level, or as a large sand bar along a river. This means that the entire potentially 12,000 year prehistory of the region is contained in the upper $30 \mathrm{~cm}$.

Jenny Lake We revisited site 48TE576, the Jenny Lake Campground site, and saw several small likely hearths eroding from the surface along with several flakes.

\section{Shadow Mountain Quad}

Kelly Warm Springs. This site, 48TE449, was mapped and tested earlier in the summer by Mr. Bartholomew. A $50 \times 50 \mathrm{~cm}$ test pit was excavated to a depth of 95 $\mathrm{cm}$, and cultural material was found to a depth of 40 $\mathrm{cm}$. We augured to a depth of slightly more than $1 \mathrm{~m}$ before encountering impenetrable gravel but found no further evidence of occupation than that recovered in the test pit.

\section{Moose Quad}

South BlackTail Butte. We revisited site 48TE400 (and the locality just to the south discovered by Reher's survey team previously) which was recorded previously in the summer. This site sits on what seemed to be a thick deposit of loess and we were curious as to whether there was any buried occupation there as well. Two auger holes placed into this site show that the loess deposit here is deep--in excess of two meters--but no evidence of a buried occupation was found.

Ditch Creek. We surveyed the immediate edges of Ditch Creek to the east and west of Mormon Row looking specifically for buried paleosols (Figure 8). We located a nice exposure containing two buried paleosols, one about $40 \mathrm{~cm}$ below the surface and another about 75 below. Samples were taken from each of these for dating. An auger test about 25 meters from the creek's cutbank, however, was not able to recover unambiguous evidence of these two soils. Further work will be needed to determine if these soils extend beyond the immediate confines of the creek channel. No archaeological material was found in these buried soils. These soils are more or less observable right to the point where the survey ceased (where an irrigation pipe crosses Ditch Creek). West of Mormon Road the modern soil rests directly on Pleistocene cobbles for nearly a half mile, but then a loess deposit appears with one possible buried soil in evidence (these cutbanks were not as carefully examined as those to the east of Mormon Row).

The two paleosol samples returned ages of $3240 \pm 40$ B.P. $\left({ }^{13} \mathrm{C} /{ }^{12} \mathrm{C}=-24.9\right.$ o/oo; Calibrated to 3560 to 3375 B.P.; Beta lab number 134063) and an age of $1220 \pm 40$ B.P. $\left({ }^{13} \mathrm{C} /{ }^{12} \mathrm{C}=-25.4 \mathrm{o} / \mathrm{oo}\right.$; Calibrated to 1260 to 1055 B.P.; Beta lab number 134064). Because the loess deposit that encompasses these soils appears to sit on a Pleistocene gravel deposit, it is unlikely that there are any Early Holocene deposits (and hence archaeological sites) to be found in the area east of Blacktail Butte.

Another buried paleosol was seen about 1.75 below ground surface in a loess profile near the base of Blacktail Butte (Figure 8); this paleosol has a lower probability of being datable, but we were unable to sample it as bison prevented our return.

We also revisited site 48TE403, on the north side of Ditch Creek just west of the road that crosses over Ditch Creek (Figure 8). We were unable to locate any archaeological material at this locality.

Timbered Island. We walked a short transect through the southern part of Timbered Island (Figure 9) as geologic maps indicated that this section of the feature is a loess deposit. Heavily forested, visibility was zero throughout most of this transect. An old twotrack road runs up the cut at the south end of Timbered Island and provided some erosional cuts, but no archaeological remains were seen here. We revisited the Sesenbach grave and found it in good condition.

BlackTail Ponds Site. We revisited site 48TE405, finding a few flakes. This site was heavily disturbed by the construction of the overlook in the past.

Snake River Terrace. We surveyed a 4 mile section of the Snake River Terraces, on the west side of the Snake River, from a short ways down river from Deadman's Bar to a short distance north of the Bar-B-C Ranch (see Figure 10). Conducted by 4 archaeologists, we were able to survey both the upper terrace as well as the lower terraces. Several isolated finds were made as well as several historic dumps/homesteads. One site 
consisted of a scatter of fire-cracked rock and quartzite flakes. An isolated obsidian biface tip was also found, which represented the only retouched stone artifact found in the entire 10 day survey.

\section{UPLANDS}

We hiked/surveyed up the Berry Creek Trail (Figure 11) and Berry Creek Cutoff--a total of about 15 miles. We were able to quickly relocate two of Wright's sites (48TE580 and 48TE581), the only ones that time and weather permitted us to visit. We then located three new locations along the trail (we were not surveying off the trail) that need further investigation. The approximate position of these localities are: N4876158, E0516424; N4875193, E0518512; N4871919, E0522943.

\section{CONCLUSIONS AND RECOMMENDATIONS}

1. The density of archaeological debris on the floor of Jackson Hole, at least in those areas surveyed, is extremely light. Given the abundance of large fauna and the fish resources of the Snake River, this is quite surprising. At the moment, we can offer no definitive explanation. It is possible that some sites are eluding us due to plant cover. But, we intentionally targeted areas that were not heavily vegetated and/or eroded. We also examined tree throw, and the backdirt of burrowing animals, finding nothing.

Recommendation: Conduct surface surveys in the spring and fall, when plant cover will be less.

2. Previous research demonstrates that in contrast to the area to the south of Jackson Lake, there is a considerable archaeological record on the natural shores of Jackson Lake. These are, of course, normally underwater.

Recommendation: Given the paucity of archaeological remains elsewhere, should the lake ever be drawn down again, it is essential that archaeological research be conducted at that time on the known sites.

3. We were both able and unable to relocate some of the sites recorded by Wright. It is possible that plant cover was responsible in many cases, but this was not true for all cases. It is possible that Wright made complete surface collections, as we know he did in some cases, and that nothing, quite literally remains of the site. It is also possible that the sites are incorrectly located on the maps.

Recommendation: Wright's site locations need to be checked, first against whatever descriptive locational data exist, to see if they agree with the map location, and secondly through site revisits. Essential to this will be some idea of whether surface collections were made, and, if so, their extent. Subsurface testing, or shovel testing in areas of limited visibility may also be required. Some information may still be held by Wright personally. Attempts by Mr. Bartholomew to contact Professor Wright at SUNY, Albany have been to no avail (including contacting Professor Wright's department Chair). An official inquiry by the NPS may prove more productive than that of a graduate student's request.

4. The Jenny Lake Campground site. This site requires rather constant maintenance.

Recommendation: new features such as hearths should be excavated and the soil kept for possible radiocarbon dates. Flakes should be mapped as they arise. The suggestion was made in the field that a useful exercise could be to 'seed' the areas along the pathways with manufactured flakes or artifacts and then monitor the site to see if they are pocketed by tourists or if they are turned in to a park ranger. These 'artifacts' could be marked with an invisible ink only observable under ultraviolet light so that they could not be confused with prehistoric debris in the future. Such an exercise could tell us how likely it is that prehistoric artifacts will be unlawfully removed from the park.

5. The uplands. It is clear that Wright's survey probably located sites as they are made visible largely by footpaths. Our very cursory search came up with three new sites along the Berry Creek Trail. Most of the sites known from the uplands have not been tested (a few tested by Bender [1983] being the only exception); in addition, those that have been dated were almost all dated by obsidian hydration in the late 1970s. We know more about this technique now and recognize that many of the dates made in the technique's early dates of development may be in error.

Recommendation: Further survey along established trails and, especially, in heavily used camping areas are needed to locate other sites. As noted above, the known sites need to be revisited and perhaps tested for carbon that could be submitted for AMS radiocarbon dates. Additionally, a more intensive obsidian hydration dating program could be undertaken using modern protocols. 
6. Finally, we do not know enough about the post-Pleistocene geomorphology of GTNP. There appears to be very little potential for uncovering Early Holocene archaeology in that part of the southern Jackson Hole that lies within the Parks boundaries.

Recommendation: Conduct a Holocene geomorphological study of the Park.

\section{THE EARLY HOLOCENE IN GRAND TETON NATIONAL PARK}

Previous research suggests that the earliest evidence of occupation in the Park is that of the 'Cody Complex', a hunting and gathering occupation some 9000 years old. Evidence of occupation before this date is scanty at best; a few Folsom spear points (10,000 - 10,800 years old) have been found outside the Park's boundaries, and Connor (1998) illustrates a fragment of a biface that could be a Clovis point $(10,900-11,200$ years old) but the flaking pattern on this piece suggests it is not Clovis.

The park contains a complicated record of glaciation, but for our purposes, this record is not highly significant since the park was generally free of ice by $14,000 \mathrm{BP}-$ before humans were probably even present in North America. We know that some parts of Jackson Hole have seen massive post-glacial deposition-in places, especially around Jackson Lake, e.g., the Willow Flats area, Early Holocene deposits are 70-100 feet below the surface. Yet, in other places, such as the Potholes region, the ground surface has not been modified much since the last glacial advance, the Jackson Lake Phase of the Pinedale glaciation. Our research this summer suggests that the area around Pacific Creek may contain some deeply (but not too deeply) buried deposits. Alternatively, it could be that all Early Holocene material was eroded from this drainage during the arid, Altithermal climatic interval (10,000-6000 BP). The south end of the Park has seen loess deposition in places, as noted in the Ditch Creek profiles and the auger holes at the BlackTail Butte site. Early Holocene material here may also be buried, although not to the extent that it is in the Willow Flats area. On the other hand, all Early Holocene deposits in this region, as well as the Pacific Creek drainage, may have been removed during the arid Altithermal Interval. This means that the potholes region is an area that holds some of the best promise for revealing Early Holocene sites--either buried sites or surface sites. To date, however, this most promising area has not provided significant results.
Not only is there no Early Holocene material here, there is almost no prehistoric archaeology at all. This is extremely puzzling. It is possible that when people occupied Jackson Hole, that occupation focused entirely on the now-inundated lakeshores. But, is seems likely that the Snake River would also have been as attractive as the lake, and the areas away from the lake and the river should have been attractive as hunting areas. Using the area between the lake and river as a hunting zone should have resulted in numerous small sites, or a low density but more or less continuous scatter of archaeological remains. But we see no evidence for either pattern. Although further survey is needed to clarify this, it seems unlikely that either vegetation (that might obscure surface visibility) or deposition could account for this pattern. Our final recommendation is that we are not yet prepared to erect a tombstone over a search for the Early Holocene archaeology in GTNP.

\section{LiTERATURE CITED}

Bender, Susan. 1983. Hunter-gatherer subsistence and settlement in a mountainous environment: the prehistory of the northern Tetons. Ph.D. Dissertation, Department of Anthropology, State University of New York, Albany.

Connor, Melissa. 1998. Final report on the Jackson Lake Archaeological Project, Grand Teton National Park, Wyoming. National Park Service Midwest Archaeological Center Technical Report No. 46. 


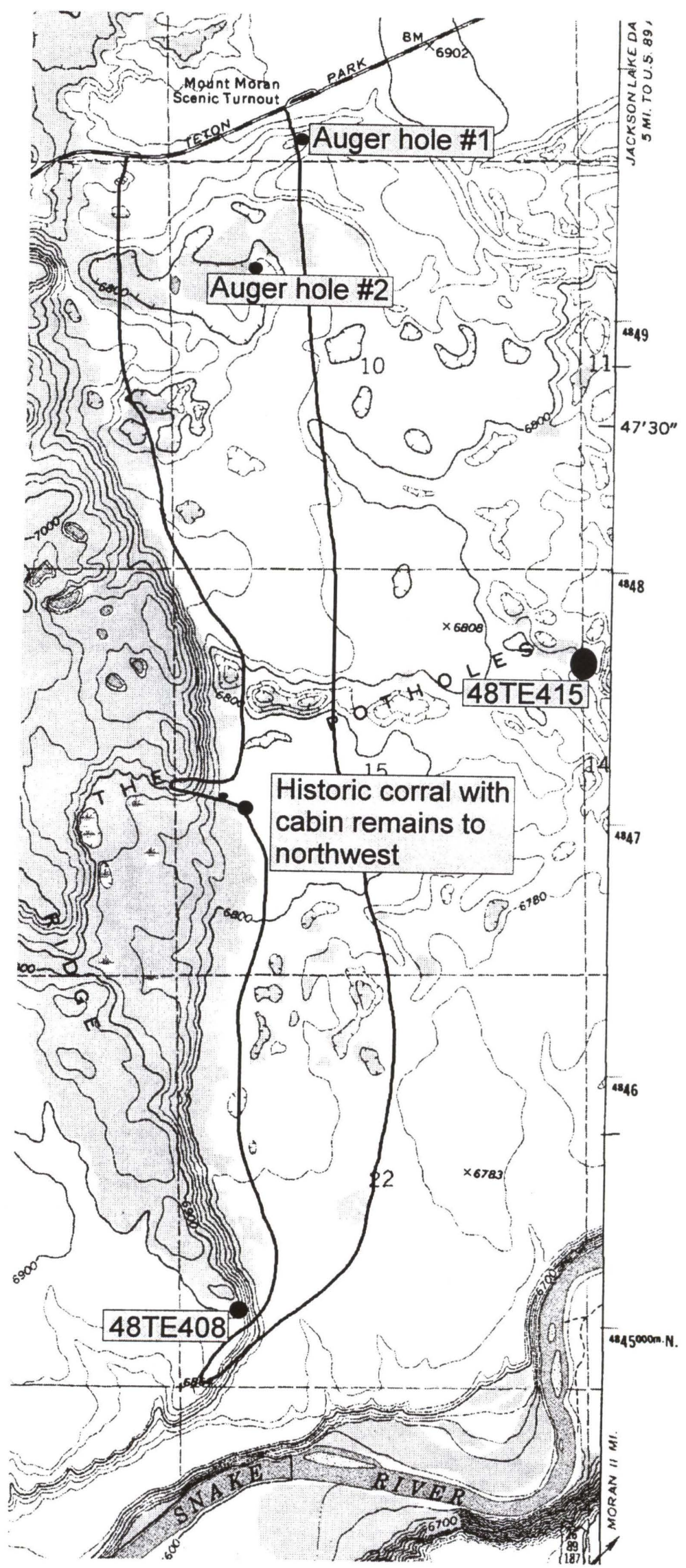

Figure 1. 


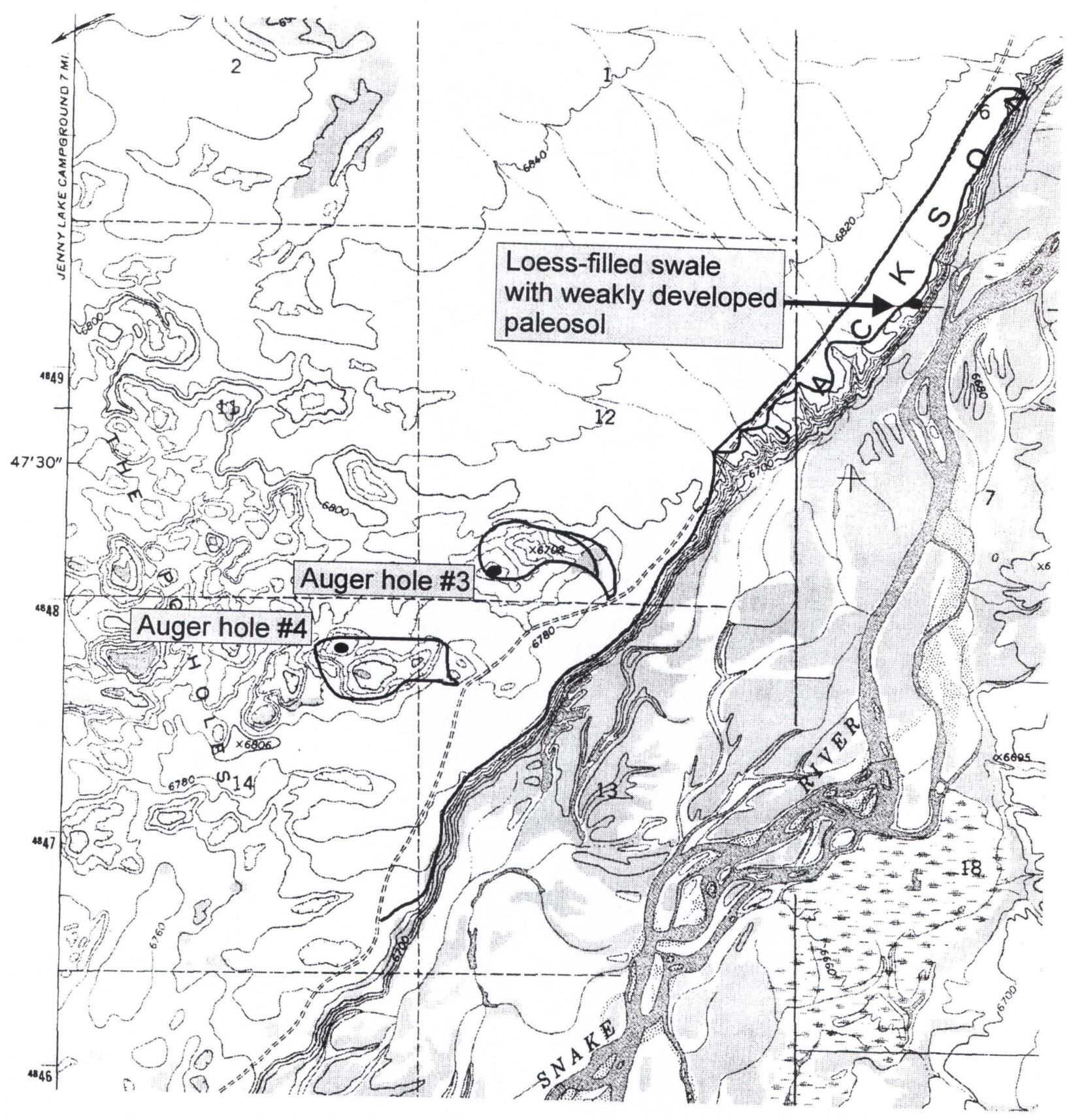

Figure 2. 


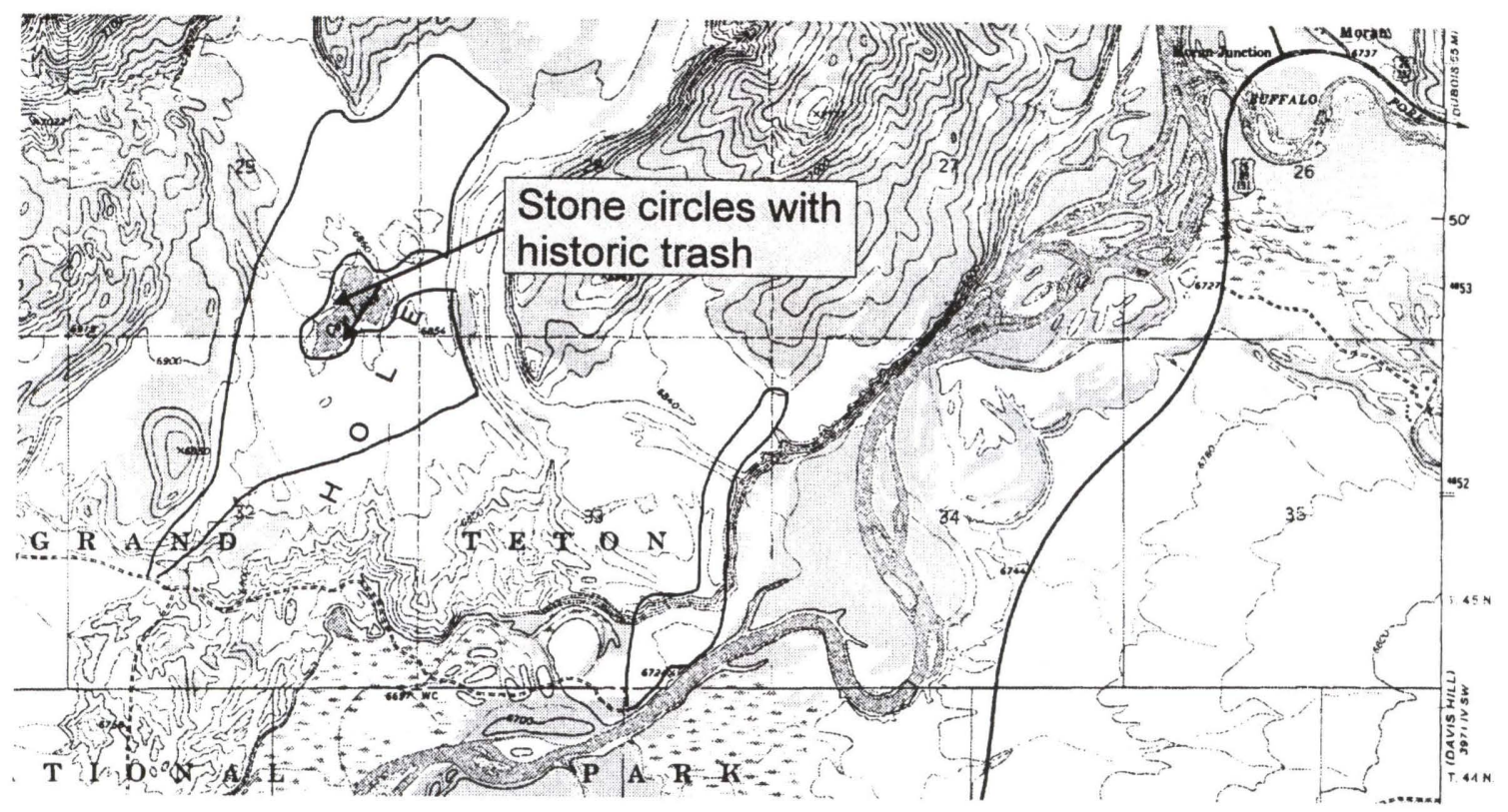

Figure 3. 
Figure 4.

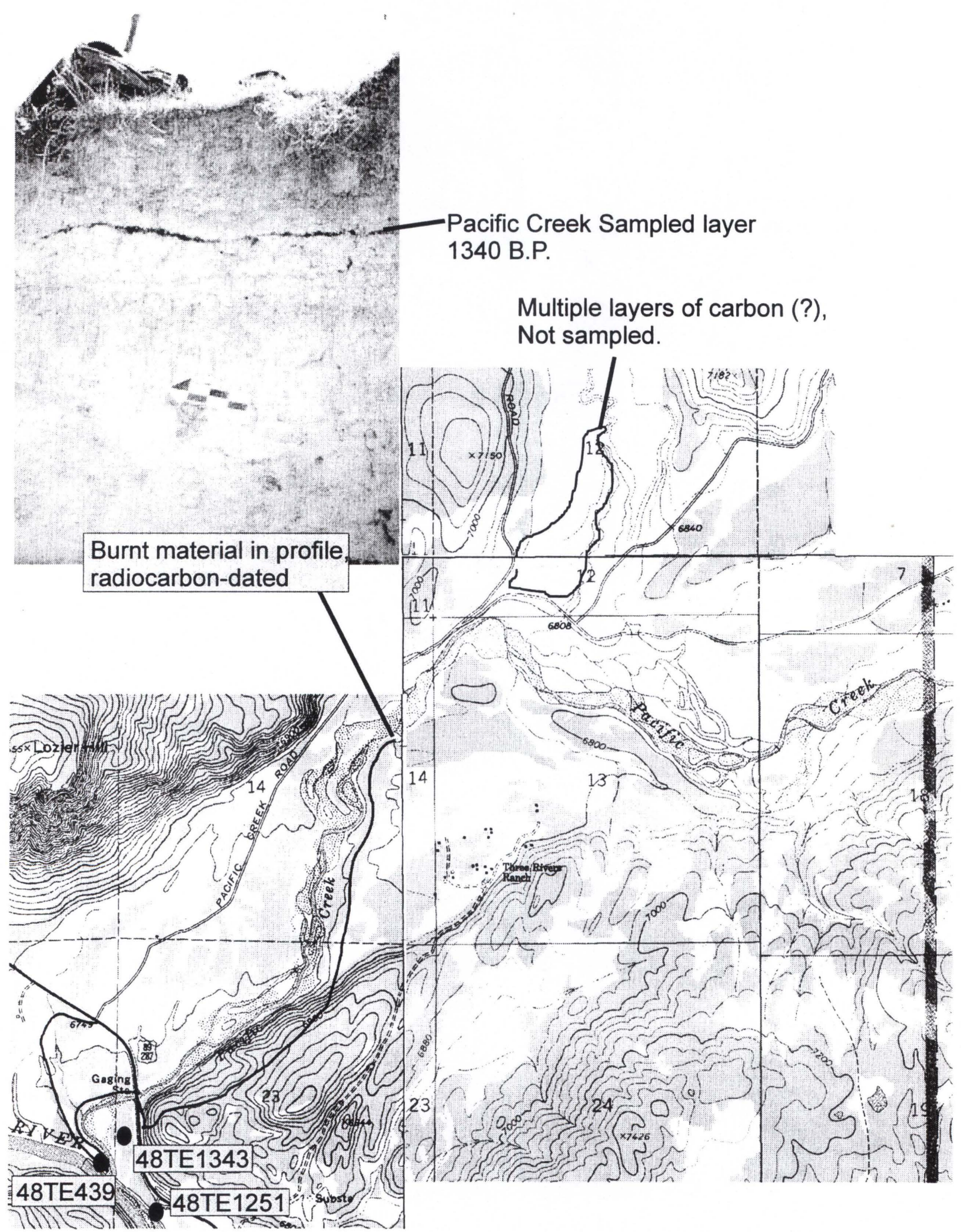




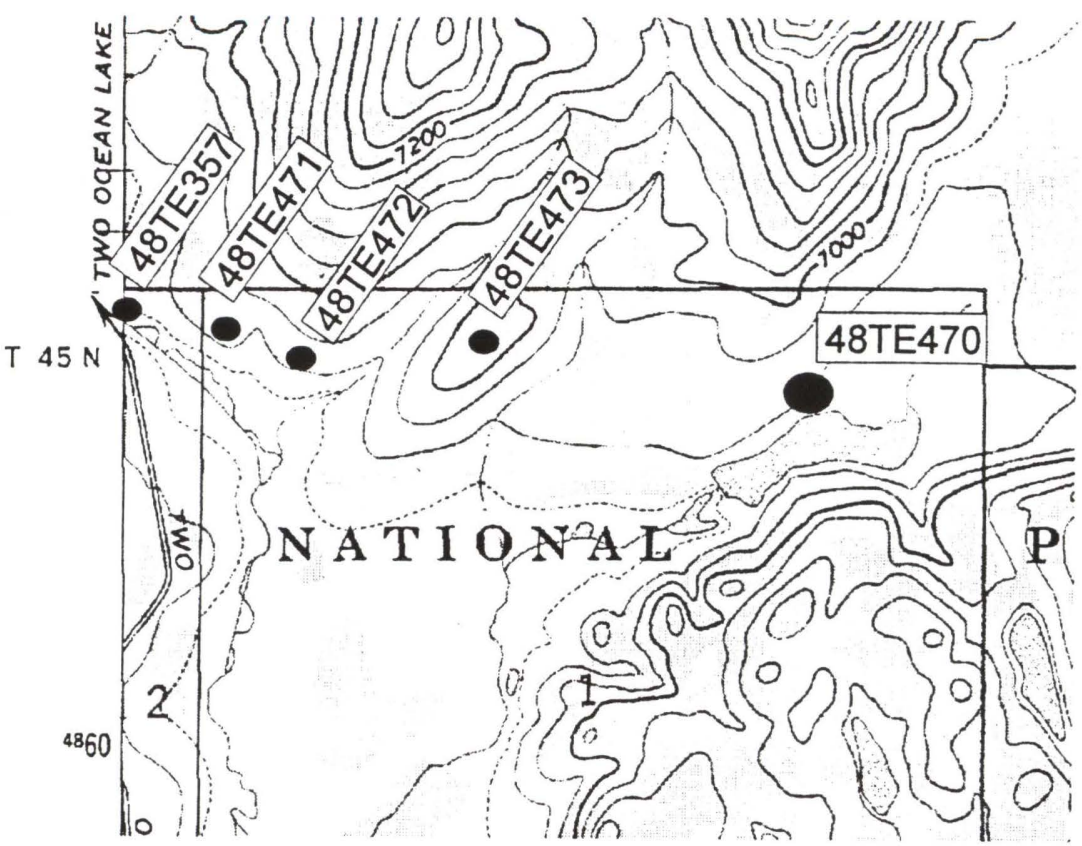

Figure 5.

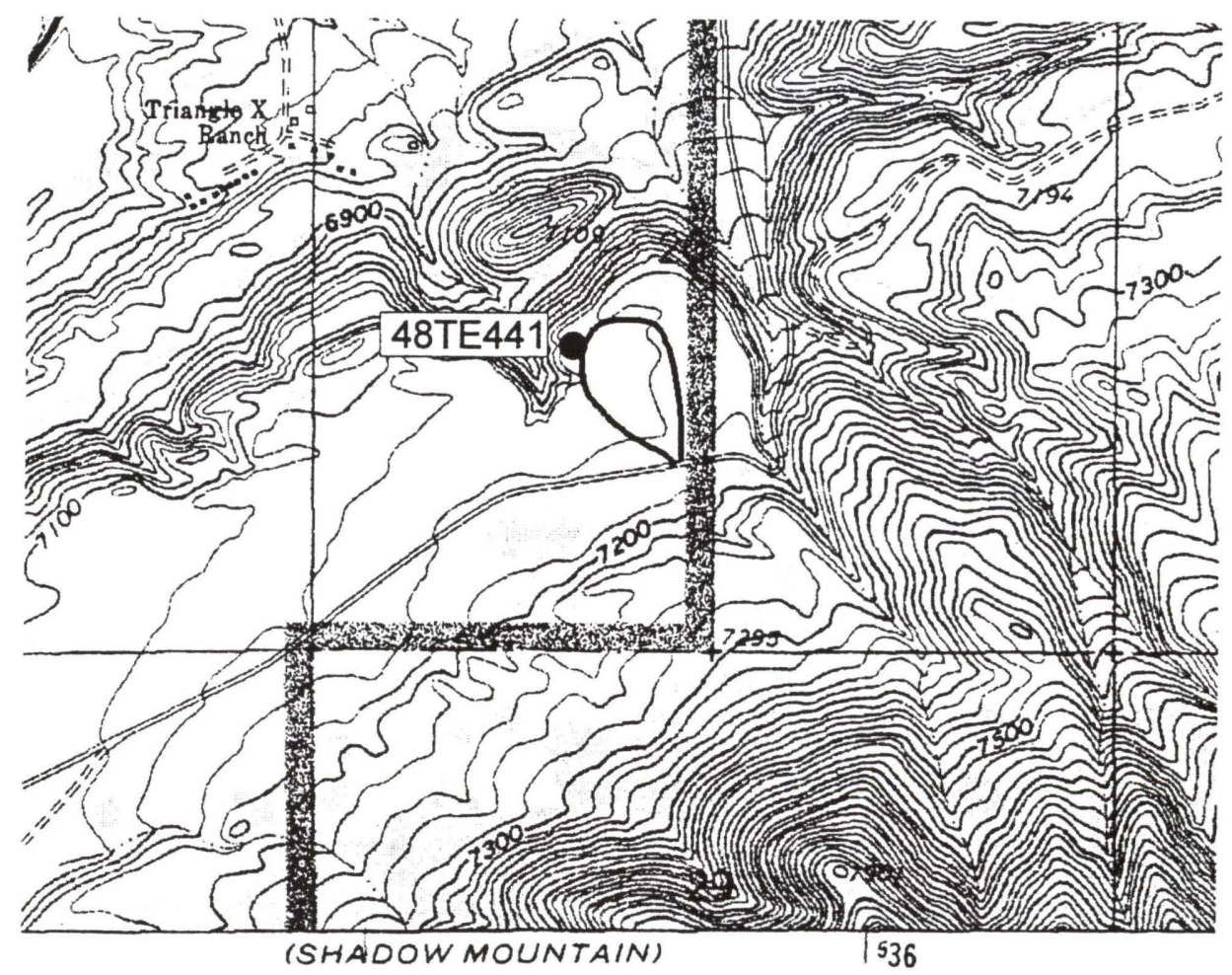

Figure 6. 


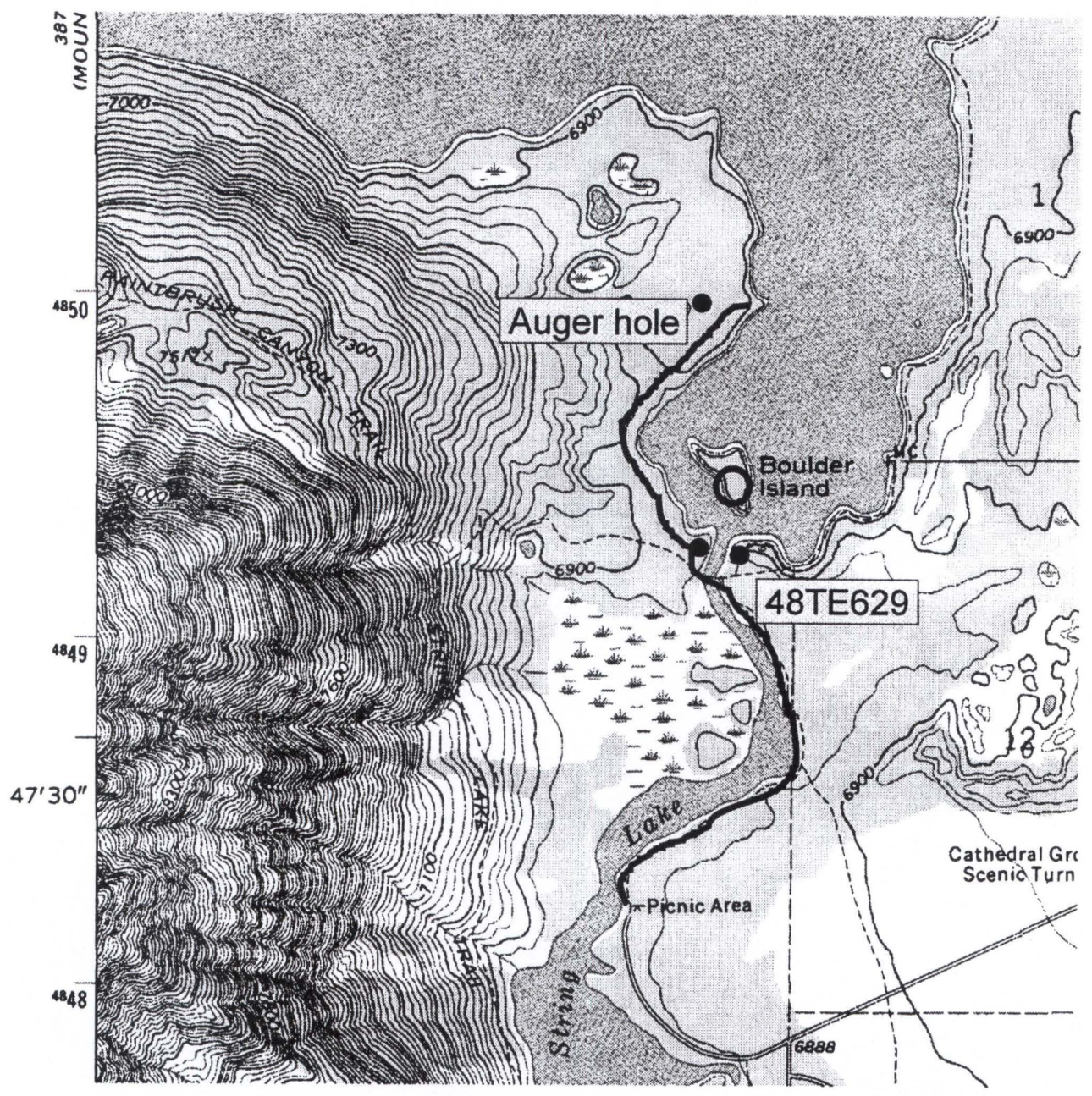

Figure 7. 

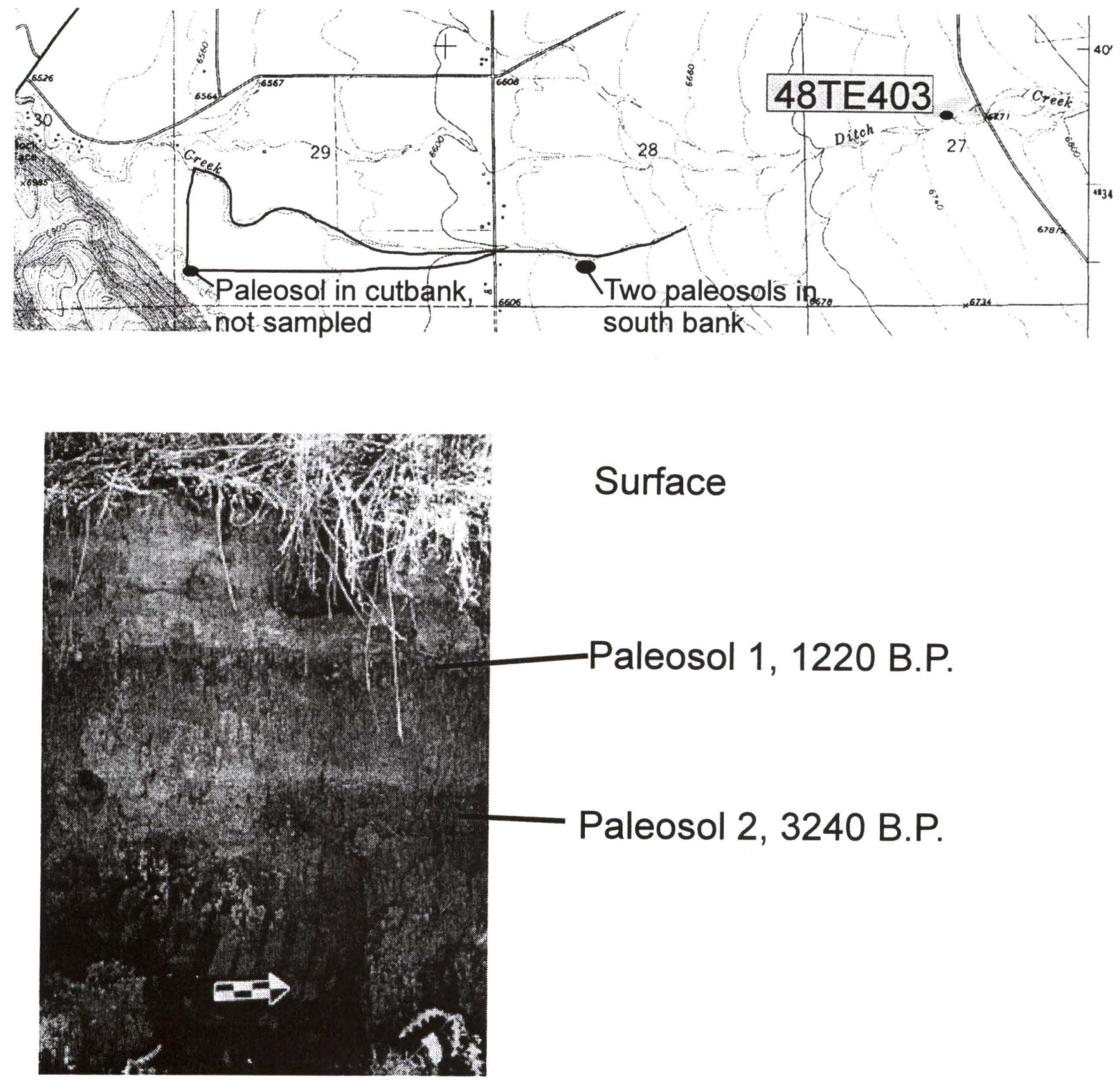

Figure 8. 


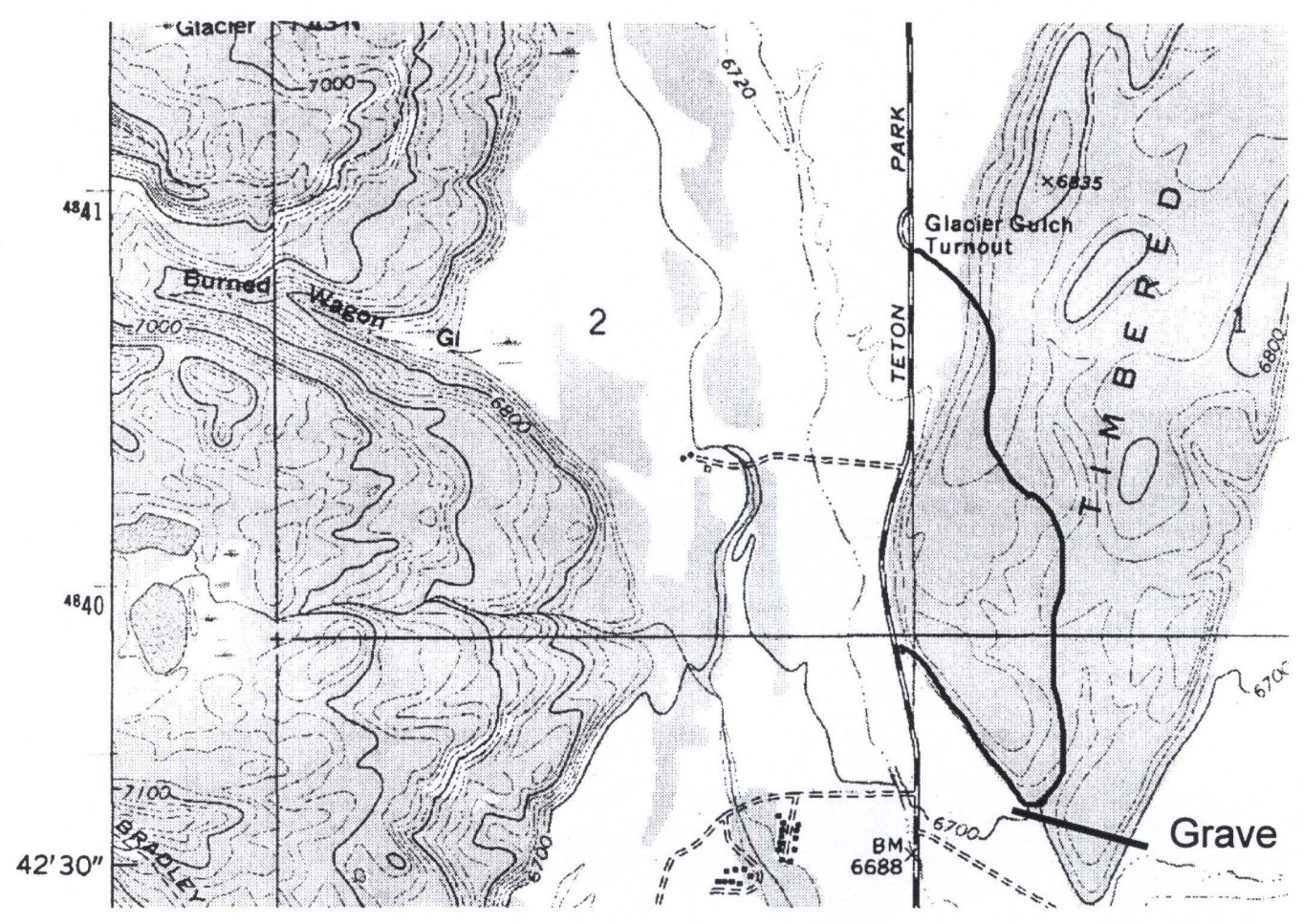

Figure 9. 


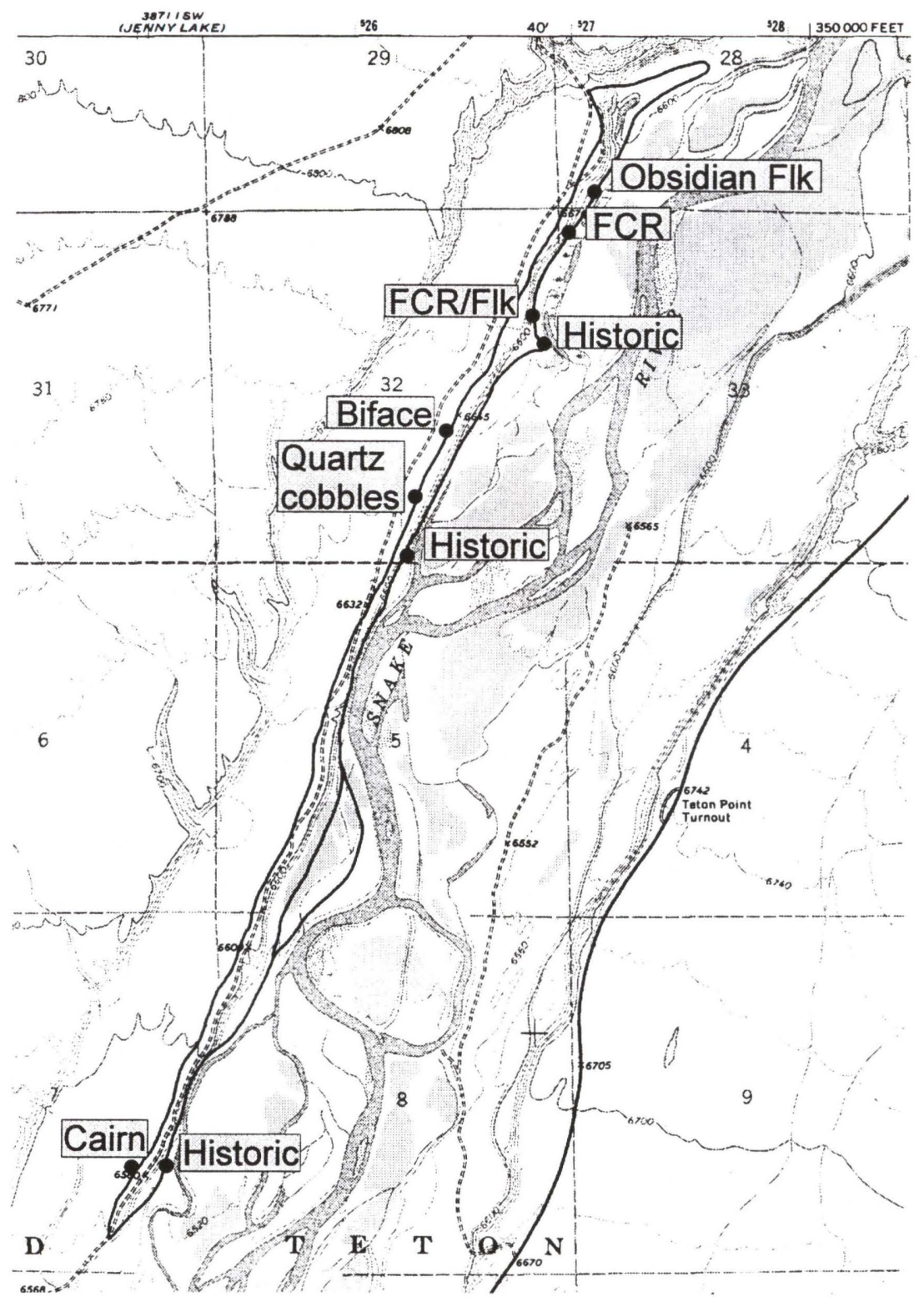

Figure 10. 


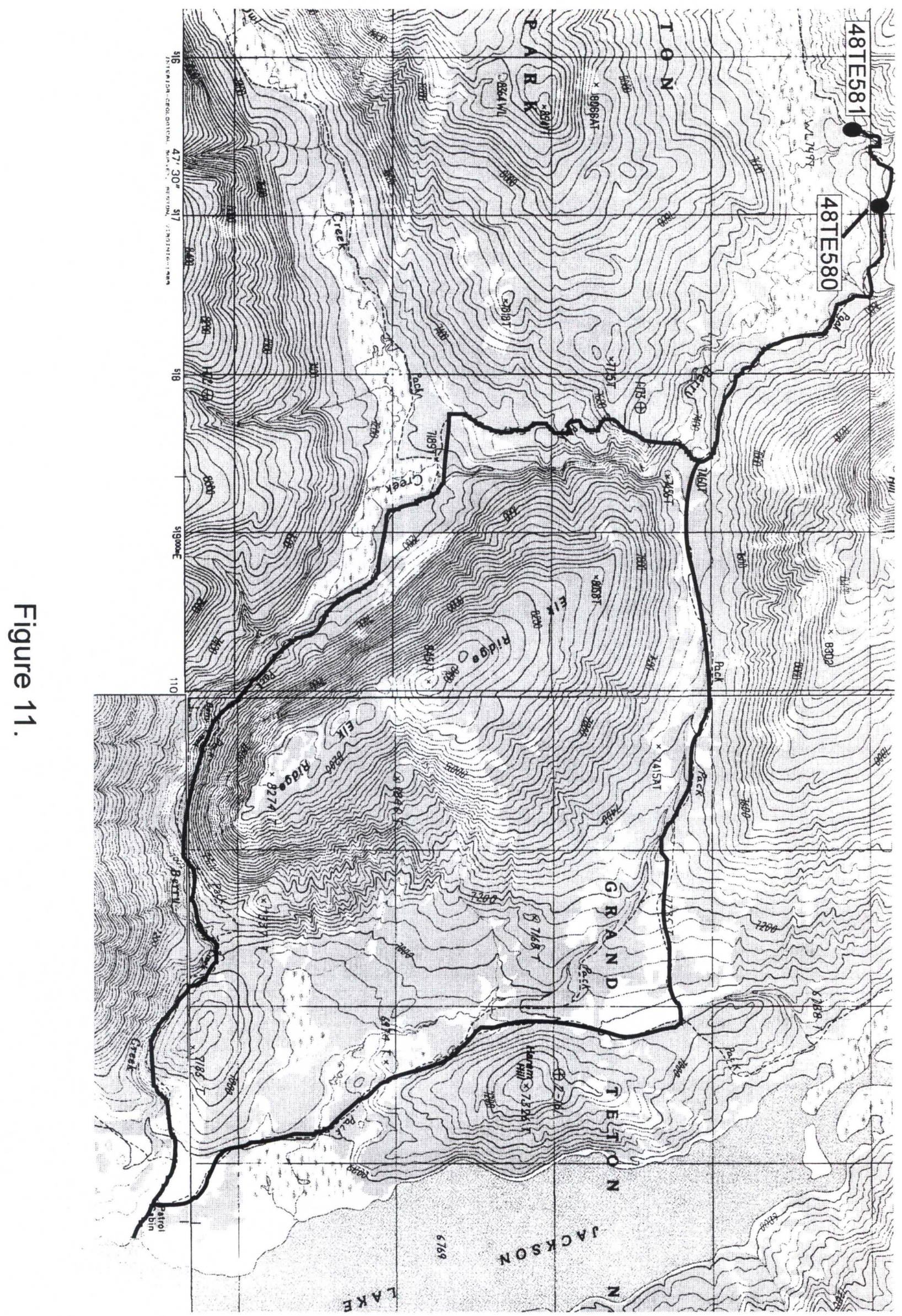

